\title{
Centuries of intense surface melt on Larsen C Ice Shelf
}

\author{
Suzanne L. Bevan ${ }^{1}$, Adrian Luckman ${ }^{1}$, Bryn Hubbard ${ }^{2}$, Bernd Kulessa ${ }^{1}$, David Ashmore ${ }^{3}$, Peter Kuipers Munneke ${ }^{4}$, \\ Martin O'Leary ${ }^{1}$, Adam Booth ${ }^{5}$, Heidi Sevestre ${ }^{6}$, and Daniel McGrath \\ ${ }^{1}$ Geography Department, College of Science, Swansea University, Singleton Park, Swansea, SA2 8PP, UK \\ ${ }^{2}$ Centre for Glaciology, Department of Geography and Earth Sciences, Aberystwyth University, \\ Aberystwyth, SY23 3DB, UK \\ ${ }^{3}$ School of Environmental Science, Roxby Building, University of Liverpool, Liverpool, L69 7ZT, UK \\ ${ }^{4}$ Institute for Marine and Atmospheric Research, Utrecht (IMAU), Utrecht University, P.O. Box 80000, \\ 3508 TA Utrecht, the Netherlands \\ ${ }^{5}$ School of Earth and Environment, University of Leeds, Leeds, LS2 9JT, UK \\ ${ }^{6}$ School of Geography and Geosciences, University of St Andrews, College Gate, St Andrews, KY16 9AJ, UK \\ ${ }^{7}$ Department of Geosciences, Colorado State University, Fort Collins, Colorado, USA \\ Correspondence to: Suzanne L. Bevan (s.1.bevan@swansea.ac.uk)
}

Received: 3 May 2017 - Discussion started: 30 May 2017

Revised: 9 October 2017 - Accepted: 1 November 2017 - Published: 5 December 2017

\begin{abstract}
Following a southward progression of ice-shelf disintegration along the Antarctic Peninsula (AP), Larsen C Ice Shelf (LCIS) has become the focus of ongoing investigation regarding its future stability. The ice shelf experiences surface melt and commonly features surface meltwater ponds. Here, we use a flow-line model and a firn density model (FDM) to date and interpret observations of meltaffected ice layers found within five $90 \mathrm{~m}$ boreholes distributed across the ice shelf. We find that units of ice within the boreholes, which have densities exceeding those expected under normal dry compaction metamorphism, correspond to two climatic warm periods within the last 300 years on the Antarctic Peninsula. The more recent warm period, from the 1960s onwards, has generated distinct sections of dense ice measured in two boreholes in Cabinet Inlet, which is close to the Antarctic Peninsula mountains - a region affected by föhn winds. Previous work has classified these layers as refrozen pond ice, requiring large quantities of mobile liquid water to form. Our flow-line model shows that, whilst preconditioning of the snow began in the late 1960s, it was probably not until the early 1990s that the modern period of ponding began. The earlier warm period occurred during the 18th century and resulted in two additional sections of anomalously dense ice deep within the boreholes. The first, at $61 \mathrm{~m}$ in one of our Cabinet Inlet boreholes, consists of ice characteristic of refrozen ponds and must have formed in an
\end{abstract}

area currently featuring ponding. The second, at $69 \mathrm{~m}$ in a mid-shelf borehole, formed at the same time on the edge of the pond area. Further south, the boreholes sample ice that is of an equivalent age but which does not exhibit the same degree of melt influence. This west-east and north-south gradient in the past melt distribution resembles current spatial patterns of surface melt intensity.

\section{Introduction}

With an area of $\sim 47000 \mathrm{~km}^{2}$, Larsen C Ice Shelf (LCIS) on the eastern Antarctic Peninsula (AP) is currently the fifth largest ice shelf in Antarctica. Following the southward progression of ice-shelf disintegration along the AP since the 1950s, including the loss of Prince Gustav and Larsen A in 1995 (Rott et al., 1996) and Larsen B in 2002 (Rack and Rott, 2004), the stability of LCIS would seem to be at risk. In 2000, LCIS was closely bounded to the north and west by the $-9^{\circ} \mathrm{C}$ surface mean annual isotherm considered to be the northerly limit of AP ice-shelf viability (Morris and Vaughan, 2003) with lower mean annual temperatures on the shelf. In recent decades at least, LCIS, and particularly its northern sector, has exhibited a number of factors that are indicative of instability: surface lowering (Shepherd et al., 2003; Fricker and Padman, 2012; Holland et al., 2015) at an 
increasing rate (Paolo et al., 2015), firn air depletion (Holland et al., 2011), recession (Cook and Vaughan, 2010), and surface ponding (Luckman et al., 2014). In July 2017 a rift, which began propagating from the south in 2014 (Jansen et al., 2015; Borstad et al., 2017), caused $\sim 10 \%$ of the iceshelf area to break away (Hogg and Gudmundsson, 2017).

Surface lowering and ice-shelf thinning on LCIS is a result of both firn air depletion and basal ice loss (Holland et al., 2015). The basal ice loss may be a result of reductions in ice accretion or of increases in melt or flow divergence; firn air may become depleted because of reductions in accumulation or because of enhanced surface melt and refreezing within the firn. The areas on LCIS with low firn air (Holland et al., 2011), to the north and in the lee of the mountains, coincide with areas where annual melt duration is longest and where föhn winds influence the surface (Luckman et al., 2014). A föhn wind is an orographic phenomenon that, on LCIS, occurs under moderate to strong westerly flow and leads to warm and dry air displacing the prevailing cool near-surface conditions (Elvidge et al., 2015).

Recent trends in surface melt parameters on the Antarctic Peninsula, such as onset date, duration, or intensity, depend on the time period under consideration. During the second half of the 20th century, mean annual temperatures were increasing (Vaughan et al., 2003) and melt trends, based on sums of positive degree days (PDDs) from the few meteorological stations operational during this period, showed increases significant at the $95 \%$ confidence level or better (Vaughan, 2006). When analyses include the first decade of the 21 st century, during which time AP mean annual temperatures decreased (Turner et al., 2016), the trends based on PDDs remained positive but less steep (Barrand et al., 2013). The various studies do, however, reveal a large amount of interannual variability, with annual meltwater volume varying by a factor of 4 during the period from 1979 to 2010 (Kuipers Munneke et al., 2012).

During years in which surface melt periods are long and intense, widespread ponds may form on ice shelves. Such ponds have been proposed as a trigger for ice-shelf break-up, either by enhancing the hydrofracture of existing crevasses (Scambos et al., 2000; MacAyeal et al., 2003; van den Broeke, 2005; McGrath et al., 2012) or via the stresses induced by hydrostatic rebound following drainage (MacAyeal and Sergienko, 2013), which may lead to runaway disintegration (Banwell and MacAyeal, 2015). Spatially extensive surface ponding occurred on both Larsen A and B prior to break-up (Sergienko and MacAyeal, 2005). Such extensive ponding has yet to be observed on LCIS but Holland et al. (2011) highlighted Cabinet Inlet on the Foyn Coast of LCIS (Fig. 1) as a particular location where observations in optical satellite images of surface melt ponding coincide with low firn air content and with low backscatter in summertime synthetic aperture radar images, which is indicative of high surface water content. A recent study based on a borehole drilled in Cabinet Inlet, profiles of temperature and density,

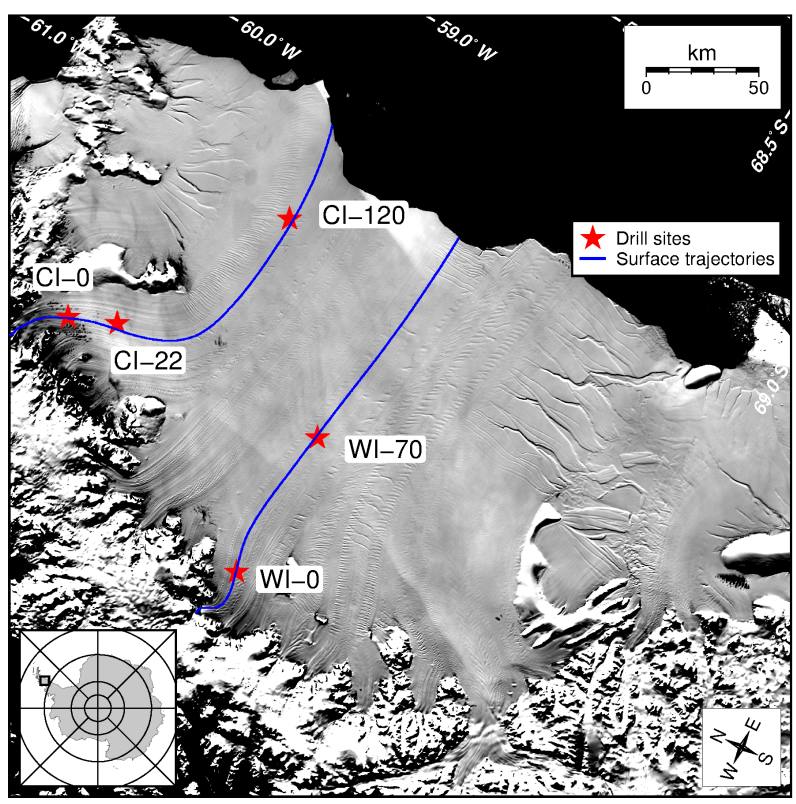

Figure 1. Mosaic of Antarctica (MOA2009) image of Larsen C Ice Shelf (Scambos et al., 2007; Haran et al., 2014) with borehole locations and Cabinet and Whirlwind Inlet surface flow trajectories.

ground-penetrating radar, firn density modelling, and satellite images identified a massive subsurface body of anomalously warm and dense ice (Hubbard et al., 2016). This body of ice was interpreted to be the result of the intense melt and regular surface ponding that occurs in this area.

The effect of föhn-induced melting and ponding on the englacial properties of the ice shelf downstream depends on the history of surface melt and consequently how far along flow its temperature and density legacy has been advected. Almost all surface meltwater that percolates down through the snow and firn refreezes in the firn and releases latent heat, thereby increasing the density and the temperature of the subsurface layers (Vaughan, 2008) and changing the rheology of the ice shelf. The increase in temperature reduces the viscosity of the ice allowing enhanced ice flow relative to colder ice, potentially increasing lateral rifting and leading to the possibility of ice-shelf break-up (Rack and Rott, 2004). The increase in density may, however, compensate for the temperature effect by increasing the fracture toughness and stabilizing the ice against crevassing (Rist et al., 2002; Jansen et al., 2010). Without direct observations of density and temperature, modelling experiments designed to investigate the stability of the ice shelf must tune rheological parameters to minimize the misfit between modelled and observed velocity fields (e.g. Vieli et al., 2007; Furst et al., 2016).

In late 2015 we drilled four boreholes in addition to that reported by Hubbard et al. (2016), consisting of two directly downstream from Cabinet Inlet and two downstream from Whirlwind Inlet (Fig. 1). The $90 \mathrm{~m}$ boreholes were drilled and viewed using an optical televiewer (OPTV) at site CI-0 
in November 2014 and at the four other sites, CI-22, CI-120, WI-0, and WI-70, in November and December 2015 (Fig. 1). The OPTV borehole images, with a pixel size of $1 \mathrm{~mm}^{2}$, provide information about the material composition and structure of the borehole walls (Hubbard et al., 2008). Firn density may be derived from the luminosity of the recorded image (Hubbard et al., 2016) and relies on an empirical relationship between image brightness and density, with lower reflectivity corresponding to denser ice (Hubbard et al., 2013).

The five borehole images are described in detail in Hubbard et al. (2016) and Ashmore et al. (2017); in summary, across the sites, four different ice types, or units, were identified on the basis of visual appearance, density, and refrozen ice content. Image thresholding was used to determine the proportion of ice within each unit that is composed of refrozen infiltration ice. Unit 1 (U1) is the uppermost unit and is the only unit observed in all boreholes: this layer is interpreted as accumulated snow or firn undergoing compaction metamorphism with sporadic but spatially widespread layers formed by melt-refreeze events. Unit 2 (U2) is present only at depth at site CI-120 and is composed of ice that has experienced enhanced compaction owing to higher temperatures and surface melt; the host ice is dense but refrozen layers are still visible within the column. Unit 3 (U3) occurs only at CI-0 and CI-22 and is interpreted as refrozen pond ice (Hubbard et al., 2016). The ice in U3 is homogeneous with only diffuse layering. Extreme melt events are required to allow a sufficient quantity of mobile meltwater to percolate down and add to the previous upper surface of U3. Finally, Unit 4 (U4) is the least dense of all the units, containing steeply dipping layers of deformed ice, and is identified as continental ice originating from upstream of the grounding line. U4 is present at the base of the CI-0 and WI-0 boreholes.

Ashmore et al. (2017) concluded that the large quantities of refrozen ice within the boreholes suggest that intense melt is spatially pervasive and has been ongoing on LCIS for decades or even centuries. In this study we use a flow-line model to investigate where and when various units of meltaffected ice observed within the Cabinet Inlet and four other boreholes originated, relate the origins to past local climate, and estimate how much of the ice shelf will have been affected by various intensities of surface melt.

\section{Data and methods}

\subsection{Flow-line model}

Following Craven et al. (2009) and McGrath et al. (2014), a flow-line model was constructed for LCIS which simulates the advection and submergence of surface layers along trajectories passing through the borehole sites. We define trajectory as the surface route based on velocity information only. From any specified starting point, surface trajectories which allow the path length through and hence time spent in each grid cell to be determined were created.

Following any trajectory, the rate of change of thickness of a surface layer $Z$ is given by

$\frac{\mathrm{D} Z}{\mathrm{D} t}=\frac{\partial Z}{\partial t}+\boldsymbol{u} \frac{\partial Z}{\partial x}=Z \dot{\epsilon}_{z}+\dot{a}+\boldsymbol{u} \frac{Z}{H} \frac{\partial H}{\partial x}$,

where $\boldsymbol{u}$ is the along-flow velocity, $\dot{\epsilon}_{z}$ is the vertical strain rate, $\dot{a}$ is the surface mass flux rate, and $H$ is the ice-shelf thickness, sampled from Bedmap2 (Fretwell et al., 2013). Equation (1) allows us to determine the three-dimensional path from the surface and through the ice shelf of an ice particle; we will refer to this path as a flow line.

Surface trajectories that passed directly through CI-0 and through WI-0 and subsequently within $1 \mathrm{~km}$ of each of the downstream borehole sites were generated. The upstream and downstream limits of these trajectories were determined by the spatial extent of the velocity data. Next, a series of flow lines were initiated at selected points along the trajectories so that from these points the accumulated snow and ice thicknesses match the depths of the interfaces between the different units at each of the borehole sites.

\subsection{Velocity data}

The trajectory routing was based on flow vectors from the $450 \mathrm{~m}$ version of the NASA Making Earth System Data Records for Use in Research Environments (MEaSUREs) Antarctic velocity dataset (Rignot et al., 2011c, b). The same velocity dataset, smoothed with a low-pass $4.5 \mathrm{~km}$ Gaussian filter, was used to calculate the strain rate along each trajectory. In order to estimate the sensitivity of our results to velocity we recomputed the along-flow rates of accumulation and submergence using $\pm 10 \%$ velocity magnitudes (Fig. $4 \mathrm{a}$ and $b$ ). This percentage change is a conservative estimate of velocity error, which was estimated to be a maximum of $17 \mathrm{~m} \mathrm{yr}^{-1}$ (Rignot et al., 2011b).

\subsection{Surface mass flux}

Surface mass fluxes were computed using the Regional Atmospheric Climate Model (RACMO2) adapted for simulations of polar climate. Annual means of surface mass balance (SMB) for the period 1979-2014 were calculated for a domain covering the AP and surrounding seas at a horizontal resolution of approximately 5.5 by $5.5 \mathrm{~km}$ (van Wessem et al., 2015). The surface mass flux rate along each profile, $\dot{a}$ in Eq. (1), was based on the median rate, with errors based on upper and lower quartiles, over the 1979-2014 period (Fig. 4a and b). Since this paper was reviewed for publication, an observationally constrained improved reconstruction of LCIS 1979-2015 mean SMB has become available (Kuipers Munneke et al., 2017), which exhibits values $\sim 10 \%$ higher than our upper uncertainty bound along each trajectory. Despite this apparently improved dataset being 

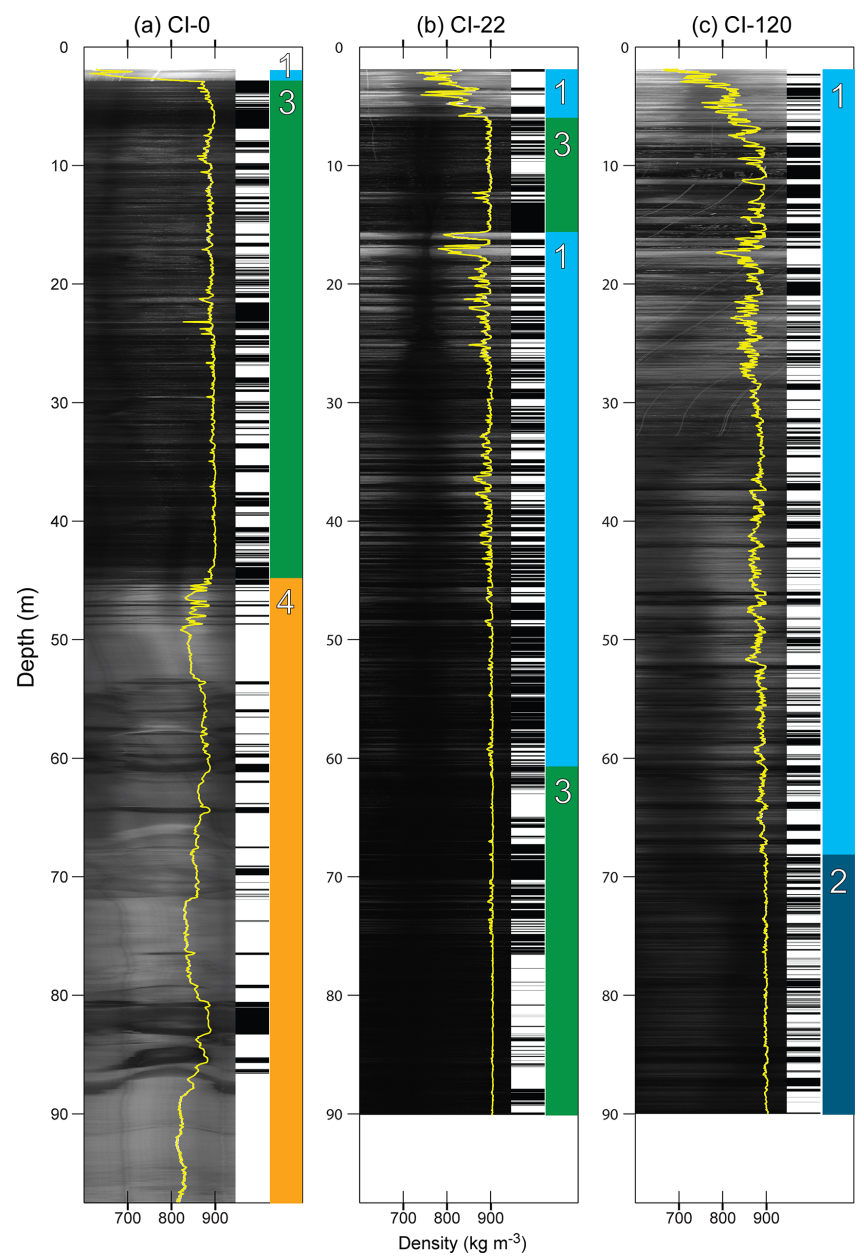

Figure 2. OPTV images, density profiles, unit classifications, and binary thresholding output for boreholes at (a) CI-0, (b) CI-22, and (c) CI-120. The grey shading represents the recorded luminosity of the ice, and the white profile represents the inferred density using the $x$-axis scale. The coloured panels are the different ice type units referred to in the text. The black stripes in the barcode-like panels show the presence of refrozen ice determined via a binary thresholding analysis which was deemed to perform poorly for Unit 3 ice (Ashmore et al., 2017). The figures are reproduced from Ashmore et al. (2017) where the methods are described in more detail.

available prior to final publication, we have not updated our analysis because the new dataset will not significantly impact on our results, discussion, or conclusions and is probably not an improvement for the context in which we are using it. In short, we are necessarily approximating a long chronology (more than 300 years) of values using a relatively short contemporary SMB field. In this context, the new reconstruction will not offer an improvement especially as there is some evidence for accumulation rates having increased by over $10 \%$ in Antarctic coastal regions since the 1960s (Frezzotti et al., 2013), and therefore the lower SMB values from our original dataset are probably a better representation of the longerterm estimate.

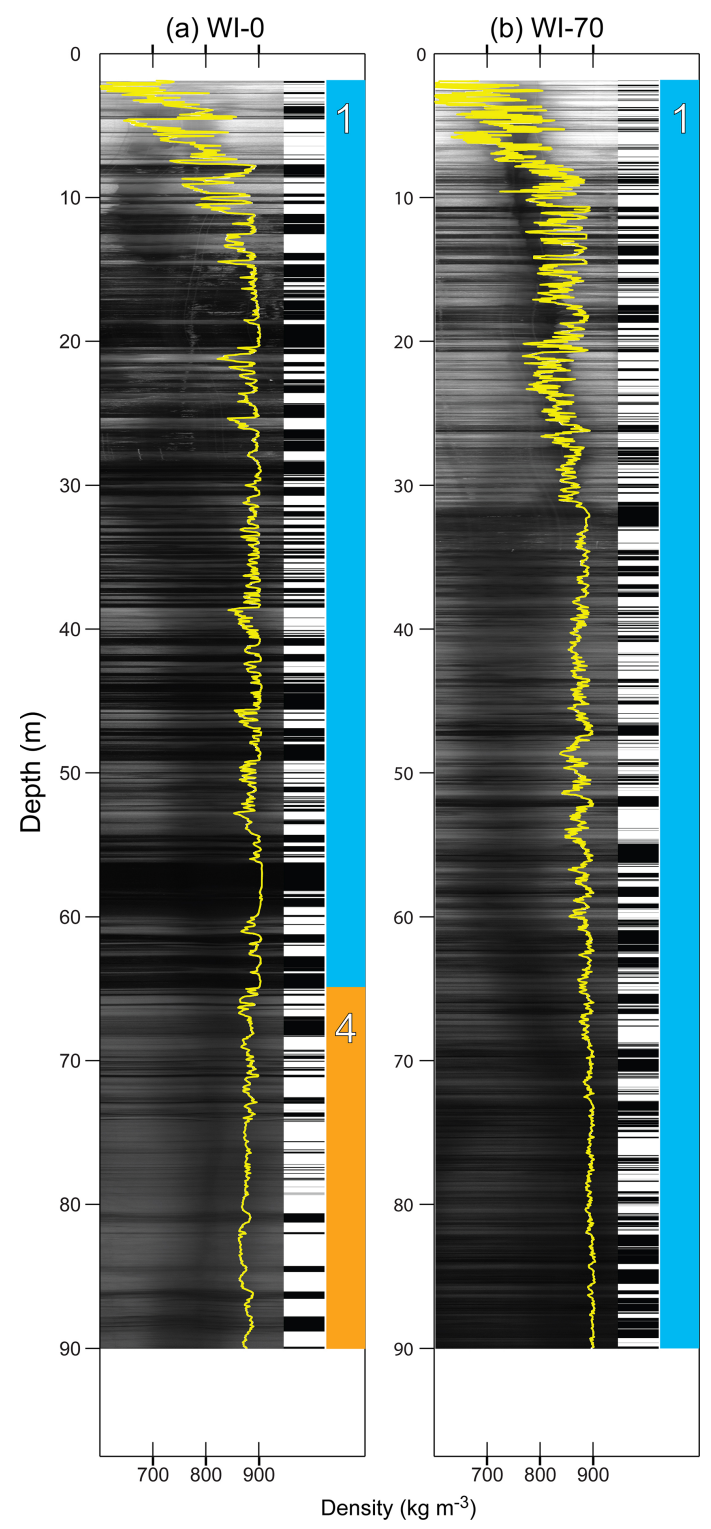

Figure 3. OPTV images, density profiles, unit classifications, and binary thresholding output for boreholes at (a) WI-0 and (b) WI22. See Fig. 2 caption for more information.

We converted surface mass fluxes to thickness using density derived from our borehole profiles (Ashmore et al., 2017) from borehole CI-120 along flow lines from Cabinet Inlet and WI-70 along flow lines from Whirlwind Inlet. CI-120 densities range from less than $700 \mathrm{~kg} \mathrm{~m}^{-3}$ at a depth of $2 \mathrm{~m}$ to $903 \mathrm{~kg} \mathrm{~m}^{-3}$ at a depth of $90 \mathrm{~m}$ (Fig. 2c). WI-70 densities are less than $600 \mathrm{~kg} \mathrm{~m}^{-3}$ at a depth of $\sim 2 \mathrm{~m}$ and $\sim 900 \mathrm{~kg} \mathrm{~m}^{-3}$ at $90 \mathrm{~m}$ (Fig. 3b). At each step along the flow line, after accumulating the appropriate amount of surface mass, the density was adjusted to the depth-mean density appropriate to the total thickness accumulated up to that point. In this way we modelled the natural compression of accumulated firn as it was advected downstream. 

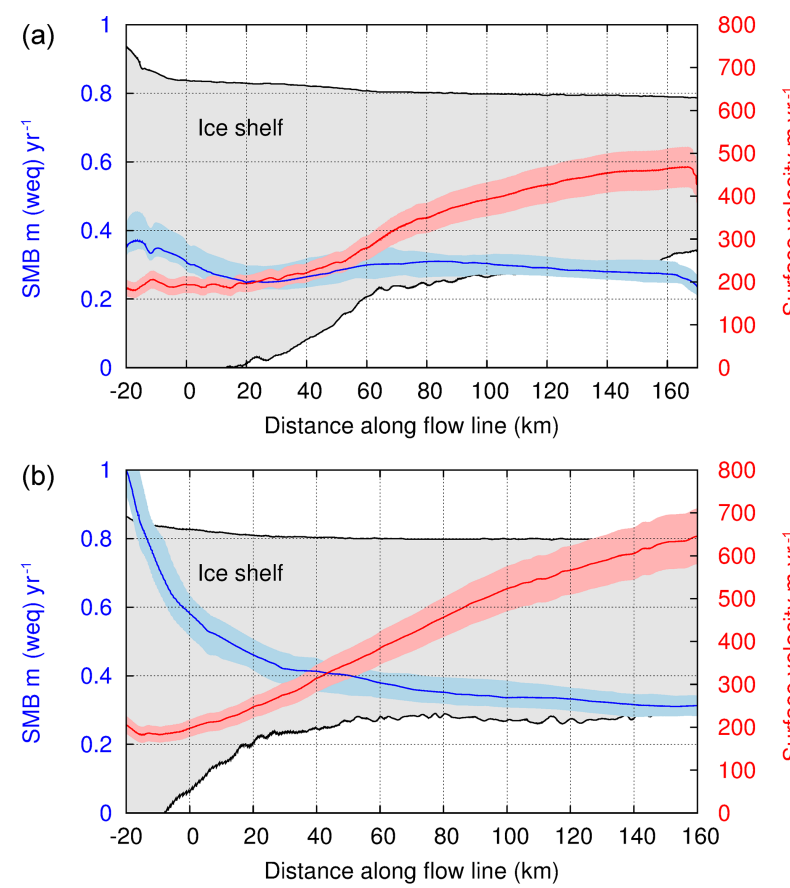

Figure 4. Along-flow profiles of surface mass balance and velocity used for (a) the Cabinet Inlet trajectory and (b) the Whirlwind Inlet trajectory. The shaded boundaries represent the uncertainty estimates as described in the text. See Fig. 5a and b for the scale for the grey-shaded ice-shelf outlines.

\subsection{Firn density model}

In order to predict the time evolution of the near-surface firn density profile at a single location within Cabinet Inlet we ran a one-dimensional firn densification and hydrology model (FDM) (Ligtenberg et al., 2011). The model is driven by mass fluxes, wind speed, and surface temperature from RACMO2 and takes into account firn compaction, meltwater percolation, and refreezing.

\section{Results}

Each flow line, triggered from a point along each of the Cabinet and Whirlwind Inlet trajectories, allows an age to be estimated for the transition or interface between the units observed in the borehole images and also for the bases of the boreholes (Table 1). We convert the ages to dates by taking 2015, the year of the latest borehole observations, to be year 0 . The flow lines also pinpoint where on the ice-shelf surface the transition between units originated (Fig. 5a and b). Uncertainties in dates and distances travelled may be a result of measurement (velocity, density) or model (SMB) error. They may also result from conditions having changed through time, although Glasser et al. (2009) argued that the persistence of surface features down flow suggests minimal change in flow speed and direction over at least the last
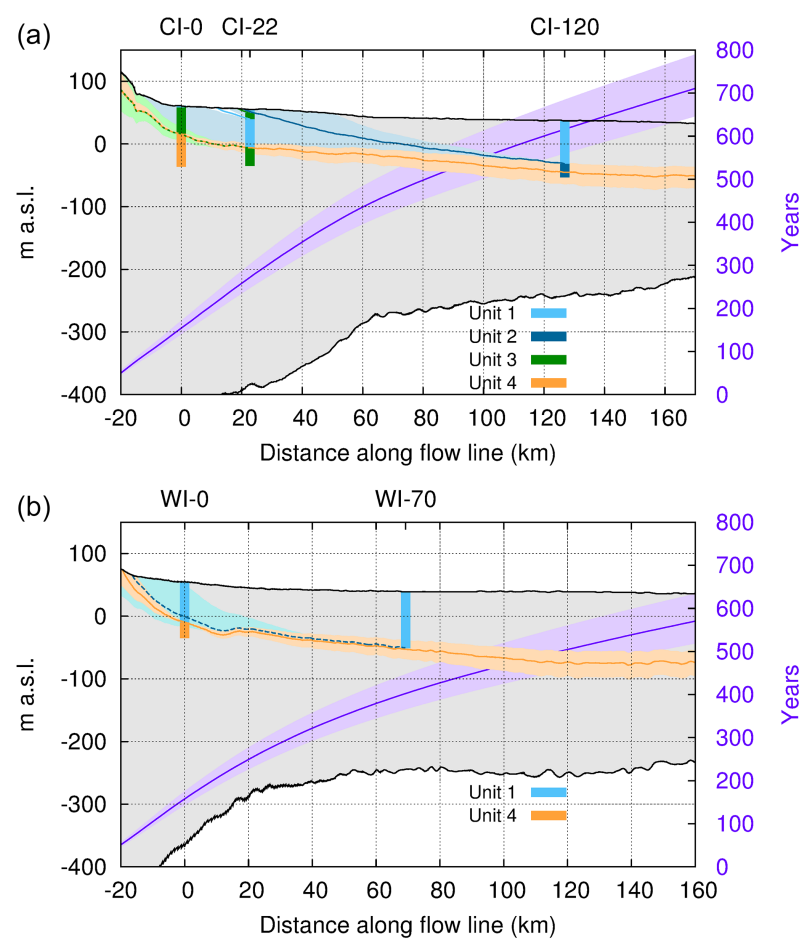

Figure 5. Flow lines initiated along trajectories from the grounding line towards the ice-shelf edge for (a) Cabinet Inlet and (b) Whirlwind Inlet. The timescale is from the beginning of the trajectory. The borehole ice units correspond to those described in Ashmore et al. (2017) and are described in the text. The shaded boundaries represent the uncertainty estimates as described in the text.

560 years. The date ranges given in parentheses in Table 1 and the shaded bounds in Fig. 5a and b are the result of using the lower quartile of SMB combined with $+110 \%$ velocity magnitude and the upper quartile of SMB combined with $90 \%$ velocity magnitude.

No dates are calculated for the bases of CI- 0 and WI- 0 as they originate upstream of the available velocity data. From the start of the flow line to the edge of the shelf, each trajectory is about $200 \mathrm{~km}$ in length, and we calculate it takes $\sim 870$ and $\sim 588$ years for the ice to be transported from Cabinet Inlet and from Whirlwind Inlet, respectively (Fig. 5a and b).

The time-dependent FDM output for CI-0 from steady state in 1979 until 2014 shows the variation in firn accumulation over glacier ice (density $917 \mathrm{~kg} \mathrm{~m}^{-3}$ ) driven by the ratio of melt to accumulation processes (Fig. 6). Throughout the time series the firn is interspersed with high-density layers caused by intermittent melt events. A major melt event in 1992-1993 removed all firn, and the subsequent years of high melt combined with low accumulation left the dense ice within a metre of the surface until 2009. By 2014, as reported in Hubbard et al. (2016), a $2.9 \mathrm{~m}$ layer of firn had re-established, which is consistent with the borehole observations. 
Table 1. Depths of the unit interfaces observed in borehole images (Ashmore et al., 2017), and age of surface origin based on the flowline modelling. Ages in parentheses are the uncertainty ranges.

\begin{tabular}{llrll}
\hline Borehole & Unit interface & Depth $(\mathrm{m})$ & \multicolumn{2}{l}{ Date of origin } \\
\hline CI-0 & U1-U3 & 2.9 & $\mathrm{a}$ & \\
& U3-U4 & 44.87 & 1873 & $\left({ }^{\mathrm{b}}-1897\right)$ \\
& Base & 97.50 & $\mathrm{~b}$ & \\
\hline CI-22 & U1-U3 & 5.9 & 1998 & $(1997-2000)$ \\
& U3-U1 & 15.64 & 1957 & $(1948-1970)$ \\
& U1-U3 & 61.68 & 1772 & $(1755-1809)$ \\
& Base & 90.0 & 1745 & $(1720-1769)$ \\
\hline CI-120 & U1-U2 & 68.56 & 1661 & $(1461-1775)$ \\
& Base & 90.0 & 1401 & $\left({ }^{b}-1564\right)$ \\
\hline WI-0 & U1-U4 & 64.95 & 1911 & $(1890-1926)$ \\
& Base & 90.0 & $\mathrm{~b}$ & \\
\hline WI-70 & Base & 90.0 & 1683 & $\left({ }^{\mathrm{b}}-1740\right)$ \\
\hline
\end{tabular}

$\mathrm{a}=$ Value not resolvable. ${ }^{\mathrm{b}}=$ Value dates back to before the trajectory start.

\section{Interpretation and discussion}

Interfaces between the ice units identified in the borehole $\operatorname{logs}$, when traced back to the surface using the flow-line model, may be interpreted in terms of either spatial or temporal changes in surface melt. For example, a transition from U1 (a unit with only sporadic melt layers) down into U2 (a unit with a high proportion of melt-refreeze) within a borehole might be a result of ice flow having passed from a region of high to low melt conditions or a result of a temporal switch from high to low surface melt conditions at the time the ice in transition was at the surface. In discussing the transitions we refer to the upper and younger unit first and then the lower and older unit; for example, the boundary between U3 and $\mathrm{U} 4$ at $\mathrm{CI}-0$ is referred to as U3-U4.

\subsection{Continental ice, U4}

In Cabinet Inlet the origin of the continental ice, marked by the U3-U4 transition, can be traced back $22 \mathrm{~km}$ upstream of CI- 0 , which equates to an advection time of $\sim 142$ years and an origin date of $\sim 1873$ (Fig. 5a). The U3-U4 origin coincides with the grounding line based on visual inspection of MODIS imagery (Bohlander and Scambos, 2007) but is about $12 \mathrm{~km}$ upstream of the grounding line identified using differential satellite radar interferometry (Rignot et al., 2011a) which marks where the ice first goes afloat. For Whirlwind Inlet the corresponding transition, this time U1-U4 (Fig. 5b), takes place $9 \mathrm{~km}$ downstream of both the MODIS and the interferometric grounding lines. This $9 \mathrm{~km}$ discrepancy may indicate grounding-line retreat over the last 100 years or an overestimation by the model of SMB close to the base of the mountains. Modelled SMB is almost a factor of 2 higher at the grounding line than it is at WI-0 (Fig. 4b).

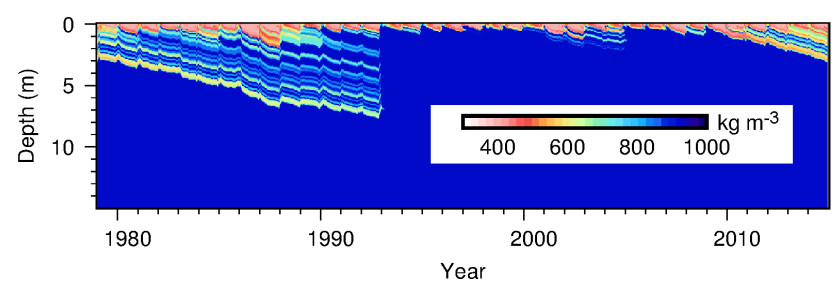

Figure 6. Time evolution of firn density as a function of depth for Cabinet Inlet, predicted by the firn density model (Ligtenberg et al., 2011).

Thus the flow-line model confirms that U4 in both CI- 0 and WI-0 borehole logs is continental ice, which is in line with Ashmore et al. (2017).

Continuing the flow line to trace the U3-U4 interface downstream from CI-0 predicts U4 to be at a depth of $61 \mathrm{~m}$ by the time it reaches CI-22. Ashmore et al. (2017) did not identify any continental ice within the $90 \mathrm{~m}$ borehole, suggesting that SMB within Cabinet Inlet may be underestimated; the lower depth based on error bounds puts $\mathrm{U} 4$ at $89 \mathrm{~m}$ at CI-22. Farther downstream from Cabinet and Whirlwind Inlet, the modelled depths of U4 are (at 82 and $92 \mathrm{~m}$ ) just above and just below the bases of the CI-120 and WI-70 boreholes, respectively. In broad agreement with McGrath et al. (2014), we find that approaching the edge of the ice shelf locally accumulated meteoric ice accounts for between 40 and $50 \%$ of the ice column. Luckman et al. (2012) observed and modelled basal crevasse penetration heights to be limited to $\sim 200 \mathrm{~m}$; our modelling suggests that this is mostly below the depths of locally accumulated meteoric shelf ice. Therefore, if basal crevasses are found only in continental or basal accreted ice, firn compaction under climate warming may not be a factor which would contribute to increasing penetration depths.

\subsection{Refrozen pond water, U3}

U3 ice, which by its nature would have required sufficient surface melt to allow percolation and refreezing in continuous vertical units, and probably also surface ponding, is only observed in the Cabinet Inlet boreholes (Fig. 2). At CI-0, it lies beneath $2.9 \mathrm{~m}$ of $\mathrm{U} 1$ and extends to a depth of $44.87 \mathrm{~m}$, and at CI-22 the upper section of U3 is covered by $5.9 \mathrm{~m}$ of U1. The lower section of U3 at CI-22 extends from $61.68 \mathrm{~m}$ to the base at $90 \mathrm{~m}$.

CI-0 was logged in November 2014, and the $2.9 \mathrm{~m}$ of U1 had a 6-year period of accumulation with no evidence, either from firn density modelling or in satellite images (Hubbard et al., 2016; Ligtenberg et al., 2011), of ponding. We do observe ponding in MODIS imagery of Cabinet Inlet during early 2015, prior to CI-22 being logged in November 2015 . However, CI-22 is $\sim 2 \mathrm{~km}$ downstream of the area of observed ponding. We can use the lower boundaries of the U3 sections to estimate the earliest date at which surface ponds 
could have been forming, although the potentially mobile nature of large volumes of meltwater means that the actual origins of U3 could have been much later in time and farther downstream. For the U3-U4 interface at CI-0 $(44.87 \mathrm{~m})$ this date is $\sim 1873$, and it is $\sim 1957$ for the U3-U1 interface at CI-22 (15.74 m) (Table 1). The earliest date we can identify ponds in optical satellite imagery is in a Landsat 5 image for 2 February 1997; this does not mean that ponds were not present before this date, only that none have been observed in cloud-free images. The FDM model (Fig. 6) suggests that 1993 was the first year, at least within the 1979-2015 interval, that the firn was capable of supporting ponds.

There is ample evidence from station observations of significant warming in the AP region during the second half of the 20th century including the Orcadas (Zazulie et al., 2010) and Vernadsky stations (Turner et al., 2005). Isotopic analyses of ice cores from Ferrigno on the coast of West Antarctica (Thomas et al., 2013) and Gomez on the southwestern AP (Thomas et al., 2009) as well as of borehole temperatures on the Bruce Plateau (Zagorodnov et al., 2012) also indicate a warming trend since the 1950s. The Southern Hemisphere annular mode (SAM) or the Antarctic oscillation index describes the difference in zonal-mean geopotential heights between mid- and high latitudes which drives the strength and latitude of the subpolar westerly winds. In the late 1960s the SAM entered a phase of increasing positive indices, particularly in summer and fall (Thompson and Solomon, 2002; Marshall, 2003), indicating a strengthening of the Antarctic circumpolar vortex, bringing strong westerly air flow to the AP. At meteorological stations to the north-east of the AP, positive SAM indices in summer and autumn are correlated with high air temperatures (Marshall et al., 2006). Further south, the mechanisms by which the associated strong westerlies are able to increase air temperatures over LCIS include the advection of warm air over the mountains (van den Broeke, 2005; Marshall et al., 2006), the blocking of cold southerly flow from the continent (Orr et al., 2004), and the enhancement of the föhn effect (Marshall et al., 2006; Elvidge et al., 2015). A period of intense surface melt in 2001-2002, generated by unusually high frequencies of north-westerly winds, probably triggered the break-up of Larsen B Ice Shelf (van den Broeke, 2005). Föhn events on LCIS have become more common since the 1960s, are significantly ( $\geq 98 \%$ ) correlated with surface melt in the northern inlets of LCIS close to the base of the mountains (Cape et al., 2015), and have probably led to ponding in Cabinet Inlet (Luckman et al., 2014; Elvidge et al., 2015). We therefore propose, on the basis of the borehole evidence, the flow-line model results for the U3-U1 interface at CI-22 and climatology that the ponding which has led to the formation of the upper sections of U3 has become a feature of Cabinet Inlet only during the second half of the 20th century and maybe not until the early 1990s.

Constraining the time period for recent ponding to around 50 years means that the $42 \mathrm{~m}$ of U3 at CI- 0 must also have accumulated over a similar period - much less than the 142 years indicated by the model. Either we are underestimating the SMB in the model or there is a significant amount of lateral influx of meltwater, or both, in the region upstream of CI-0. Both the modelled depth of the U4 continental ice at CI-22 and the comparison of the U4 origin with the interferometric grounding line suggest SMB in Cabinet Inlet may be underestimated; from a modelling perspective it is the regions closest to the mountains and downstream of the dominant zonal wind component which may be most affected by poor topographic resolution. In addition, the modelled SMB close to the grounding line in Cabinet Inlet is less than $50 \%$ of that in Whirlwind Inlet (Fig. 4a and b). Lateral influx of meltwater is also a real possibility in this locality. By analogy with observations within the percolation zone of the Greenland Ice Sheet (Harper et al., 2012; Machguth et al., 2016), the formation of spatially discontinuous impermeable nearsurface layers of ice following melt-refreeze events would facilitate horizontal flow of meltwater along and across the troughs in which the melt ponds form. Vertical infiltration at the boundaries of the ice barriers would result in a horizontally heterogeneous distribution of U3 type bodies. The importance of horizontal liquid water transport and its dependence on surface slope on the Greenland Ice Sheet is emphasized by Forster et al. (2013). As described in Hubbard et al. (2016), borehole CI-0 was drilled into a melt-pond trough which might be expected to contain a local concentration of infiltration ice.

The existence of a deep section of U3 at CI-22 between $61.68 \mathrm{~m}$ and the borehole base indicates that surface ponds were also forming during an earlier period, which terminated around 1772 (1755-1809). Deuterium content analysis of a 1000-year ice core from James Ross Island (JRI), $350 \mathrm{~km}$ to the north-east of Cabinet Inlet, shows mean annual temperatures to have been rising steadily for the past 600 years (Mulvaney et al., 2012; Abram et al., 2013) but that within this period AD 1777 marked the end of one of two significant warming intervals. This warming interval repeatedly produced temperatures equivalent to those seen in the latter half of the 20th century and may have conditioned the ice in Cabinet Inlet to a density at which surface ponding could occur, in a manner similar to that which has probably been occurring since the recent AP warming which began in the mid-1950s (Zagorodnov et al., 2012; Turner et al., 2005, 2016). In other words, we find that the formation of a deep U3 section at CI-22 coincided with an anomalously warm period during the first half of the 18th century. Although the Ferrigno ice core indicated a warming in the second rather than first half of the 18th century (Thomas et al., 2013), it reveals, along with the JRI core, that the AP region has experienced a decadal-scale variability in air temperature over the past 300 to 1000 years of a similar magnitude to the 20th century warming. 


\subsection{Enhanced compaction unit, U2}

Unit 2 is only seen at the base of the borehole at CI-120 (Fig. 2). U2 is not as homogeneous as U3, but it does contain evidence of intense melt and densification exceeding that expected from compaction metamorphism alone (Ashmore et al., 2017). The top of U2 dates back to $~ 1661$ (14621775, Table 1) and to a surface origin $2 \mathrm{~km}$ up flow of CI22 , right on the edge of the föhn-affected region currently observed to host melt ponds. U2 at the base of CI-120 was therefore probably also generated by the 18th century warming discussed earlier in connection with U3 although U2 is not as dense and bubble-free as U3.

Along the trajectory originating in Whirlwind Inlet, it is only as we reach WI-70 that we predict borehole sampling of ice as old as the $\mathrm{U} 2$ and $\mathrm{U} 3$ units at the bases of the boreholes at CI-22 and CI-120, respectively. That we do not sample any $\mathrm{U} 2$ or U3 ice at WI-70 is compatible with the clear north-tosouth decrease in summer melt duration currently observed on LCIS (Barrand et al., 2013; Luckman et al., 2014).

\section{Conclusions}

We have used a flow-line model to trace the surface origins of distinct units of ice observed in boreholes across LCIS. The units are characterized by varying amounts of refrozen ice content, and their spatial and temporal origins can be interpreted in the context of microclimate variations on the ice shelf and AP climate change over the last 300 years.

From boreholes imaged along the Cabinet Inlet flow line we can deduce that warming from the mid-20th century preconditioned the surface of the ice shelf within the inlet until it became sufficiently impermeable to support surface ponds. The earliest possible date for 20th century pond formation, based on the $15.64 \mathrm{~m}$ base of U3 at CI-22, is $\sim 1957$. This date coincides with a switch to increasing positive SAM indices, a strengthening of the circumpolar vortex, and more frequent föhn events. Firn density modelling starting from 1979 indicates that the surface was able to support ponds by 1993 , and satellite observations confirm that ponds were present by the late 1990s.

Intense melt on the northern part of LCIS, and probably ponding within Cabinet Inlet, also occurred during the 18th century, corresponding with an earlier period of warming over the AP identified in ice-core temperature reconstructions. Unit 3 ice at the base of the CI-22 borehole was forming up until 1755 and $\mathrm{U} 2$ at the base of the CI-120 borehole up until 1661. Both U3 and U2 probably reflect the influence of föhn winds.

The pattern of melt reflected in the borehole logs, including the absence of U2 and U3 down flow of Whirlwind Inlet, suggests that past as well as recent melt is reflected in the current spatial distribution of firn air content (Holland et al., 2011).
By tracing the submergence of continental ice down flow, we estimate that even by the shelf edge, where the proportion of shelf ice consisting of meteoric ice is at a maximum, only the upper 40 or $50 \%$ consists of local accumulation. Below this depth the shelf ice must consist either of continental ice or accreted marine ice. This vertical heterogeneity has implications for determining the resistance of the shelf to fracture, with it being the meteoric ice that exhibits the least resistance to rifting (McGrath et al., 2014). Basal crevasses are observed to penetrate upward through only the lower $200 \mathrm{~m}$ of shelf ice and therefore will be restricted to continental or basal accreted ice and not be affected by atmospheric processes acting on the firn.

This research demonstrates that the current setting of LCIS, featuring extensive, and in places intense, surface melt and located immediately south of the boundary of AP iceshelf viability, is not without precedent in the last 300 years. The previous AP warm period in the 18 th century is captured in the stratigraphy of the shelf and is further evidence of the link between atmospheric warming and the collapse or decay of eastern AP ice shelves throughout the Holocene.

Data availability. The UK Polar Data Centre holds the flow-line model code (https://doi.org/10.5285/0cea12bf2f44-4d48-99d1-e7d303c5e80e; Bevan, 2017a) and results (https://doi.org/10.5285/d363ff21-1576-4ad6-a2e8-bbc3c0a39b06; Bevan, 2017b). The MEaSUREs Antarctic velocity dataset is available from the NSIDC (https://nsidc.org/data/nsidc-0484; Rignot et al., 2011b, c) and the Bedmap2 dataset from the British Antarctic Survey (https://secure.antarctica.ac.uk/data/bedmap2/).

Author contributions. SLB carried out the flow-line modelling and prepared the manuscript. AL led the project, BH and DA supplied the borehole data, MO'L advised on the flow-line modelling, and PKM supplied the SMB data. All authors contributed to drafting of the manuscript.

Competing interests. The authors declare that they have no conflict of interest.

Acknowledgements. The research was funded by the Natural Environment Research Council (NERC) grants NE/L006707/1 and NE/L005409/1. Navigation in the field was performed via a Leica VIVA GS10 GNSS loaned from the NERC Geophysical Equipment Facility (loan number 1028). Bryn Hubbard acknowledges Capital Equipment Grant support from the Higher Education Funding Council for Wales (HEFCW) and Aberystwyth University. The British Antarctic Survey provided logistical support in the field, and we thank our field assistants Ashley Fusiarski, Nick Gillett, Alan Davies, and Bradley Morrell. Any use of trade, firm, or product names is for descriptive purposes only and does not imply endorsement by the US Government. 
Edited by: G. Hilmar Gudmundsson

Reviewed by: Elizabeth Thomas and one anonymous referee

\section{References}

Abram, N. J., Mulvaney, R., Wolff, E. W., Triest, J., Kipfstuhl, S., Trusel, L. D., Vimeux, F., Fleet, L., and Arrowsmith, C.: Acceleration of snow melt in an Antarctic Peninsula ice core during the twentieth century, Nat. Geosci., 6, 404-411, https://doi.org/10.1038/ngeo1787, 2013.

Ashmore, D. W., Hubbard, B., Luckman, A., Kulessa, B., Bevan, S., Booth, A., Munneke, P. K., and O'Leary, M.: Ice and firn hetereogeneity within Larsen C Ice Shelf from borehole optical televiewing, J. Geophys. Res.-Earth, 122, 1139-1153, https://doi.org/10.1002/2016JF004047, 2017.

Banwell, A. F. and MacAyeal, D. R.: Ice-shelf fracture due to viscoelastic flexure stress induced by fill/drain cycles of supraglacial lakes, Antarct. Sci., 27, 587-597, https://doi.org/10.1017/s0954102015000292, 2015.

Barrand, N. E., Vaughan, D. G., Steiner, N., Tedesco, M., Kuipers Munneke, P., van den Broeke, M. R., and Hosking, J. S.: Trends in Antarctic Peninsula surface melting conditions from observations and regional climate modeling, J. Geophys. Res.Earth, 118, 315-330, https://doi.org/10.1029/2012jf002559, 2013.

Bevan, S.: Flow-line model code for accumulation of ice along velocity-based trajectories, https://doi.org/10.5285/0cea12bf2f44-4d48-99d1-e7d303c5e80e, 2017a.

Bevan, S.: Flowline model results for 2 trajectories on Larsen C Ice Shelf, https://doi.org/10.5285/d363ff21-1576-4ad6-a2e8bbc3c0a39b06, 2017b.

Bohlander, J. and Scambos, T.: Antarctic coastlines and grounding line derived from MODIS Mosaic of Antarctica (MOA), Digital Media, National Snow and Ice Data Center, Boulder, Colorado, USA, 2007.

Borstad, C., McGrath, D., and Pope, A.: Fracture propagation and stability of ice shelves governed by ice shelf heterogeneity, Geophys. Res. Lett., 44, 4186-4194, https://doi.org/10.1002/2017gl072648, 2017.

Cape, M. R., Vernet, M., Skvarca, P., Marinsek, S., Scambos, T., and Domack, E.: Foehn winds link climate-driven warming to ice shelf evolution in Antarctica, J. Geophys. Res.-Atmos., 120, 11037-11057, https://doi.org/10.1002/2015jd023465, 2015.

Cook, A. J. and Vaughan, D. G.: Overview of areal changes of the ice shelves on the Antarctic Peninsula over the past 50 years, The Cryosphere, 4, 77-98, https://doi.org/10.5194/tc-4-77-2010, 2010

Craven, M., Allison, I., Fricker, H. A., and Warner, R.: Properties of a marine ice layer under the Amery Ice Shelf, East Antarctica, J. Glaciol., 55, 717-728, https://doi.org/10.3189/002214309789470941, 2009.

Elvidge, A. D., Renfrew, I. A., King, J. C., Orr, A., Lachlan-Cope, T. A., Weeks, M., and Gray, S. L.: Foehn jets over the Larsen C Ice Shelf, Antarctica, Q. J. Roy. Meteor. Soc., 141, 698-713, https://doi.org/10.1002/qj.2382, 2015.

Forster, R. R., Box, J. E., van den Broeke, M. R., Miège, C., Burgess, E. W., van Angelen, J. H., Lenaerts, J. T. M., Koenig, L. S., Paden, J., Lewis, C., Gogineni, S. P., Leuschen, C., and McConnell, J. R.: Extensive liquid meltwater storage in firn within the Greenland ice sheet, Nat. Geosci., 7, 95-98, https://doi.org/10.1038/ngeo2043, 2013.

Fretwell, P., Pritchard, H. D., Vaughan, D. G., Bamber, J. L., Barrand, N. E., Bell, R., Bianchi, C., Bingham, R. G., Blankenship, D. D., Casassa, G., Catania, G., Callens, D., Conway, H., Cook, A. J., Corr, H. F. J., Damaske, D., Damm, V., Ferraccioli, F., Forsberg, R., Fujita, S., Gim, Y., Gogineni, P., Griggs, J. A., Hindmarsh, R. C. A., Holmlund, P., Holt, J. W., Jacobel, R. W., Jenkins, A., Jokat, W., Jordan, T., King, E. C., Kohler, J., Krabill, W., Riger-Kusk, M., Langley, K. A., Leitchenkov, G., Leuschen, C., Luyendyk, B. P., Matsuoka, K., Mouginot, J., Nitsche, F. O., Nogi, Y., Nost, O. A., Popov, S. V., Rignot, E., Rippin, D. M., Rivera, A., Roberts, J., Ross, N., Siegert, M. J., Smith, A. M., Steinhage, D., Studinger, M., Sun, B., Tinto, B. K., Welch, B. C., Wilson, D., Young, D. A., Xiangbin, C., and Zirizzotti, A.: Bedmap2: improved ice bed, surface and thickness datasets for Antarctica, The Cryosphere, 7, 375-393, https://doi.org/10.5194/tc-7-375-2013, 2013.

Frezzotti, M., Scarchilli, C., Becagli, S., Proposito, M., and Urbini, S.: A synthesis of the Antarctic surface mass balance during the last $800 \mathrm{yr}$, The Cryosphere, 7, 303-319, https://doi.org/10.5194/tc-7-303-2013, 2013.

Fricker, H. A. and Padman, L.: Thirty years of elevation change on Antarctic Peninsula ice shelves from multimission satellite radar altimetry, J. Geophys. Res., 117, C02026, https://doi.org/10.1029/2011jc007126, 2012.

Furst, J. J., Durand, G., Gillet-Chaulet, F., Tavard, L., Rankl, M., Braun, M., and Gagliardini, O.: The safety band of Antarctic ice shelves, Nat. Clim. Change, 6, 479-482, https://doi.org/10.1038/nclimate2912, 2016.

Glasser, N. F., Kulessa, B., Luckman, A., Jansen, D., King, E. C., Sammonds, P. R., Scambos, T. A., and Jezek, K. C.: Surface structure and stability of the Larsen C ice shelf, Antarctic Peninsula, J. Glaciol., 55, 400-410, https://doi.org/10.3189/002214309788816597, 2009.

Haran, T., Bohlander, J., Scambos, T., Painter, T., and Fahnestock, M.: MODIS Mosaic of Antarctica 2008-2009 (MOA2009) Image Map, Version 1, 2014.

Harper, J., Humphrey, N., Pfeffer, W. T., Brown, J., and Fettweis, X.: Greenland ice-sheet contribution to sea-level rise buffered by meltwater storage in firn, Nature, 491, 240-243, https://doi.org/10.1038/nature11566, 2012.

Hogg, A. E. and Gudmundsson, G. H.: Impacts of the LarsenC Ice Shelf calving event, Nat. Clim. Change, 7, 540-542, https://doi.org/10.1038/nclimate3359, 2017.

Holland, P. R., Corr, H. F. J., Pritchard, H. D., Vaughan, D. G., Arthern, R. J., Jenkins, A., and Tedesco, M.: The air content of Larsen Ice Shelf, Geophys. Res. Lett., 38, L10503, https://doi.org/10.1029/2011g1047245, 2011.

Holland, P. R., Brisbourne, A., Corr, H. F. J., McGrath, D., Purdon, K., Paden, J., Fricker, H. A., Paolo, F. S., and Fleming, A H.: Oceanic and atmospheric forcing of Larsen C Ice-Shelf thinning, The Cryosphere, 9, 1005-1024, https://doi.org/10.5194/tc9-1005-2015, 2015.

Hubbard, B., Roberson, S., Samyn, D., and Merton-Lyn, D.: Digital optical televiewing of ice boreholes, J. Glaciol., 54, 823-830, https://doi.org/10.3189/002214308787779988, 2008. 
Hubbard, B., Tison, J.-L., Philippe, M., Heene, B., Pattyn, F., Malone, T., and Freitag, J.: Ice shelf density reconstructed from optical televiewer borehole logging, Geophys. Res. Lett., 40, 58825887, https://doi.org/10.1002/2013g1058023, 2013.

Hubbard, B., Luckman, A., Ashmore, D. W., Bevan, S., Kulessa, B., Kuipers Munneke, P., Philippe, M., Jansen, D., Booth, A., Sevestre, H., Tison, J.-L., O'Leary, M., and Rutt, I.: Massive subsurface ice formed by refreezing of ice-shelf melt ponds, Nat. Commun., 7, 11897, https://doi.org/10.1038/ncomms11897, 2016.

Jansen, D., Kulessa, B., Sammonds, P. R., Luckman, A., King, E. C., and Glasser, N. F.: Present stability of the Larsen C ice shelf, Antarctic Peninsula, J. Glaciol., 56, 593-600, https://doi.org/10.3189/002214310793146223, 2010.

Jansen, D., Luckman, A. J., Cook, A., Bevan, S., Kulessa, B., Hubbard, B., and Holland, P. R.: Brief Communication: Newly developing rift in Larsen C Ice Shelf presents significant risk to stability, The Cryosphere, 9, 1223-1227, https://doi.org/10.5194/tc-91223-2015, 2015.

Kuipers Munneke, P., Picard, G., van den Broeke, M. R., Lenaerts, J. T. M., and van Meijgaard, E.: Insignificant change in Antarctic snowmelt volume since 1979, Geophys. Res. Lett., 39, L01501, https://doi.org/10.1029/2011g1050207, 2012.

Kuipers Munneke, P., McGrath, D., Medley, B., Luckman, A., Bevan, S., Kulessa, B., Jansen, D., Booth, A., Smeets, P., Hubbard, B., Ashmore, D., Van den Broeke, M., Sevestre, H., Steffen, K., Shepherd, A., and Gourmelen, N.: Observationally constrained surface mass balance of Larsen $\mathrm{C}$ ice shelf, Antarctica, The Cryosphere, 11, 2411-2426, https://doi.org/10.5194/tc-112411-2017, 2017.

Ligtenberg, S. R. M., Helsen, M. M., and van den Broeke, M. R.: An improved semi-empirical model for the densification of Antarctic firn, The Cryosphere, 5, 809-819, https://doi.org/10.5194/tc-5809-2011, 2011.

Luckman, A., Jansen, D., Kulessa, B., King, E. C., Sammonds, P., and Benn, D. I.: Basal crevasses in Larsen C Ice Shelf and implications for their global abundance, The Cryosphere, 6, 113-123, https://doi.org/10.5194/tc-6-113-2012, 2012.

Luckman, A., Elvidge, A., Jansen, D., Kulessa, B., Munneke, P. K., King, J., and Barrand, N. E.: Surface melt and ponding on Larsen C Ice Shelf and the impact of föhn winds, Antarct. Sci., 26, 625635, https://doi.org/10.1017/s0954102014000339, 2014.

MacAyeal, D. R. and Sergienko, O. V.: The flexural dynamics of melting ice shelves, Ann. Glaciol., 54, 1-10, https://doi.org/10.3189/2013aog63a256, 2013.

MacAyeal, D. R., Scambos, T. A., Hulbe, C. L., and Fahnestock, M. A.: Catastrophic ice-shelf break-up by an iceshelf-fragment-capsize mechanism, J. Glaciol., 49, 22-36, https://doi.org/10.3189/172756503781830863, 2003.

Machguth, H., MacFerrin, M., van As, D., Box, J. E., Charalampidis, C., Colgan, W., Fausto, R. S., Meijer, H. A. J., Mosley-Thompson, E., and van de Wal, R. S. W.: Greenland meltwater storage in firn limited by near-surface ice formation, Nat. Clim. Change, 6, 390-393, https://doi.org/10.1038/nclimate2899, 2016.

Marshall, G. J.: Trends in the Southern Annular Mode from Observations and Reanalyses, J. Climate, 16, 4134-4143, https://doi.org/10.1175/15200442(2003)016<4134:titsam>2.0.co;2, 2003.
Marshall, G. J., Orr, A., van Lipzig, N. P. M., and King, J. C.: The Impact of a Changing Southern Hemisphere Annular Mode on Antarctic Peninsula Summer Temperatures, J. Climate, 19, 5388-5404, https://doi.org/10.1175/jcli3844.1, 2006.

McGrath, D., Steffen, K., Rajaram, H., Scambos, T., Abdalati, W., and Rignot, E.: Basal crevasses on the Larsen C Ice Shelf, Antarctica: Implications for meltwater ponding and hydrofracture, Geophys. Res. Lett., 39, L16504, https://doi.org/10.1029/2012gl052413, 2012.

McGrath, D., Steffen, K., Holland, P. R., Scambos, T., Rajaram, H., Abdalati, W., and Rignot, E.: The structure and effect of suture zones in the Larsen C Ice Shelf, Antarctica, J. Geophys. Res.Earth, 119, 588-602, https://doi.org/10.1002/2013jf002935, 2014.

Morris, E. M. and Vaughan, D. G.: Spatial and temporal variation of surface temperature on the Antarctic Peninsula and the limit of viability of ice shelves, 79, 61-68, American Geophysical Union, Washington, D. C., https://doi.org/10.1029/ar079p0061, 2003.

Mulvaney, R., Abram, N. J., Hindmarsh, R. C. A., Arrowsmith, C., Fleet, L., Triest, J., Sime, L. C., Alemany, O., and Foord, S.: Recent Antarctic Peninsula warming relative to Holocene climate and ice-shelf history, Nature, 489, 141-144, https://doi.org/10.1038/nature11391, 2012.

Orr, A., Cresswell, D., Marshall, G. J., Hunt, J. C. R., Sommeria, J., Wang, C. G., and Light, M.: A 'low-level' explanation for the recent large warming trend over the western Antarctic Peninsula involving blocked winds and changes in zonal circulation, Geophys. Res. Lett., 31, L06204, https://doi.org/10.1029/2003gl019160, 2004.

Paolo, F. S., Fricker, H. A., and Padman, L.: Volume loss from Antarctic ice shelves is accelerating, Science, 348, 327-331, https://doi.org/10.1126/science.aaa0940, 2015.

Rack, W. and Rott, H.: Pattern of retreat and disintegration of the Larsen B ice shelf, Antarctic Peninsula, Ann. Glaciol., 39, 505510, https://doi.org/10.3189/172756404781814005, 2004.

Rignot, E., Mouginot, J., and Scheuchl, B.: Antarctic grounding line mapping from differential satellite radar interferometry, Geophys. Res. Lett., 38, L10504, https://doi.org/10.1029/2011g1047109, 2011a.

Rignot, E., Mouginot, J., and Scheuchl, B.: Ice Flow of the Antarctic Ice Sheet, Science, 333, 1427-1430, https://doi.org/10.1126/science.1208336, 2011 b.

Rignot, E., Mouginot, J., and Scheuchl, B.: MEaSUREs InSAR-Based Antarctica Ice Velocity Map, https://doi.org/10.5067/MEASURES/CRYOSPHERE/nsidc0484.001, 2011c.

Rist, M. A., Sammonds, P. R., Oerter, H., and Doake, C. S. M.: Fracture of Antarctic shelf ice, J. Geophys. Res., 107, ECV 2-1ECV 2-13, https://doi.org/10.1029/2000jb000058, 2002.

Rott, H., Skvarca, P., and Nagler, T.: Rapid Collapse of Northern Larsen Ice Shelf, Antarctica, Science, 271, 788-792, https://doi.org/10.1126/science.271.5250.788, 1996.

Scambos, T. A., Hulbe, C., Fahnestock, M., and Bohlander, J.: The link between climate warming and break-up of ice shelves in the Antarctic Peninsula, J. Glaciol., 46, 516-530, https://doi.org/10.3189/172756500781833043, 2000.

Scambos, T. A., Haran, T. M., Fahnestock, M. A., Painter, T. H., and Bohlander, J.: MODIS-based Mosaic of Antarctica (MOA) data sets: Continent-wide surface morphology 
and snow grain size, Remote Sens. Environ., 111, 242-257, https://doi.org/10.1016/j.rse.2006.12.020, 2007.

Sergienko, O. and MacAyeal, D. R.: Surface melting on Larsen Ice Shelf, Antarctica, Ann. Glaciol., 40, 215-218, https://doi.org/10.3189/172756405781813474, 2005.

Shepherd, A., Wingham, D., Payne, T., and Skvarca, P.: Larsen Ice Shelf Has Progressively Thinned, Science, 302, 856-859, https://doi.org/10.1126/science.1089768, 2003.

Thomas, E. R., Dennis, P. F., Bracegirdle, T. J., and Franzke, C.: Ice core evidence for significant 100-year regional warming on the Antarctic Peninsula, Geophys. Res. Lett., 36, L20704, https://doi.org/10.1029/2009g1040104, 2009.

Thomas, E. R., Bracegirdle, T. J., Turner, J., and Wolff, E. W.: A 308 year record of climate variability in West Antarctica, Geophys. Res. Lett., 40, 5492-5496, https://doi.org/10.1002/2013g1057782, 2013

Thompson, D. W. J. and Solomon, S.: Interpretation of Recent Southern Hemisphere Climate Change, Science, 296, 895-899, https://doi.org/10.1126/science.1069270, 2002.

Turner, J., Colwell, S. R., Marshall, G. J., Lachlan-Cope, T. A., Carleton, A. M., Jones, P. D., Lagun, V., Reid, P. A., and Iagovkina, S.: Antarctic climate change during the last 50 years, Int. J. Climatol., 25, 279-294, https://doi.org/10.1002/joc.1130, 2005.

Turner, J., Lu, H., White, I., King, J. C., Phillips, T., Hosking, J. S., Bracegirdle, T. J., Marshall, G. J., Mulvaney, R., and Deb, P.: Absence of 21st century warming on Antarctic Peninsula consistent with natural variability, Nature, 535, 411-415, https://doi.org/10.1038/nature18645, 2016.

van den Broeke, M.: Strong surface melting preceded collapse of Antarctic Peninsula ice shelf, Geophys. Res. Lett., 32, L12815, https://doi.org/10.1029/2005gl023247, 2005.

van Wessem, J. M., Reijmer, C. H., van de Berg, W. J., van den Broeke, M. R., Cook, A. J., van Ulft, L. H., and van Meijgaard, E.: Temperature and Wind Climate of the Antarctic Peninsula as Simulated by a High-Resolution Regional Atmospheric Climate Model, J. Climate, 28, 7306-7326, https://doi.org/10.1175/jclid-15-0060.1, 2015.
Vaughan, D.: West Antarctic Ice Sheet collapse - the fall and rise of a paradigm, Climatic Change, 91, 65-79, https://doi.org/10.1007/s10584-008-9448-3, 2008.

Vaughan, D., Marshall, G., Connolley, W., Parkinson, C., Mulvaney, R., Hodgson, D., King, J., Pudsey, C., and Turner, J.: Recent Rapid Regional Climate Warming on the Antarctic Peninsula, Climatic Change, 60, 243-274, https://doi.org/10.1023/A:1026021217991, 2003.

Vaughan, D. G.: Recent Trends in Melting Conditions on the Antarctic Peninsula and Their Implications for Ice-sheet Mass Balance and Sea Level, Arct. Antarct. Alp. Res., 38, 147-152, https://doi.org/10.1657/15230430(2006)038[0147:RTIMCO]2.0.CO;2, 2006.

Vieli, A., Payne, A. J., Shepherd, A., and Du, Z.: Causes of precollapse changes of the Larsen B ice shelf: Numerical modelling and assimilation of satellite observations, Earth Planet Sc. Lett., 259, 297-306, https://doi.org/10.1016/j.epsl.2007.04.050, 2007.

Zagorodnov, V., Nagornov, O., Scambos, T. A., Muto, A., MosleyThompson, E., Pettit, E. C., and Tyuflin, S.: Borehole temperatures reveal details of 20th century warming at Bruce Plateau, Antarctic Peninsula, The Cryosphere, 6, 675-686, https://doi.org/10.5194/tc-6-675-2012, 2012.

Zazulie, N., Rusticucci, M., and Solomon, S.: Changes in Climate at High Southern Latitudes: A Unique Daily Record at Orcadas Spanning 1903-2008, J. Climate, 23, 189-196, https://doi.org/10.1175/2009jcli3074.1, 2010 